\title{
Using E-Wallet for Business Process Development: Challenges and Prospects in Malaysia
}

\author{
Md. Mahmudul Alam * \\ School of Economics, Finance \& Banking \\ Universiti Utara Malaysia \\ 06010 UUM Sintok, Kedah, Malaysia \\ Email: rony000@gmail.com
}

\author{
Ala Eldin Awawdeh \\ Department of Management \\ Emirates College of Technology \\ Abu Dhabi, United Arab Emirates \\ Email: alaeldin.awawdeh@ect.ac.ae

\begin{abstract}
Azim Izzuddin Bin Muhamad
Universiti Teknologi MARA

Kedah, Malaysia

Email: azim03@uitm.edu.my
\end{abstract} \\ Department of Banking and Finance \\ Faculty of Business and Management \\ * Corresponding author
}

\section{Citation Reference:}

Alam, M.M., Awawdeh, A., \& Muhamad, A. I. (2021). Using E-Wallet for Business Process Development: Challenges and Prospects in Malaysia. Business Process Management Journal, 27(4), 1142-1162. (online) https://doi.org/10.1108/BPMJ-11-2020-0528

This is a pre-publication copy.

The published article is copyrighted by the publisher of the journal. 


\title{
Using E-Wallet for Business Process Development: Challenges and Prospects in Malaysia
}

\begin{abstract}
Purpose: This study aims to explore the challenges and prospects of using e-wallets in Malaysia, and what it means for businesses and customers. Suggested here are strategies to leverage the strengths and opportunities as well as overcome the weaknesses and threats. Suggested here are strategies to leverage the strengths and opportunities as well as overcome the weaknesses and threats.
\end{abstract}

Design/methodology/approach: This study analyses the e-wallet phenomenon using a SWOT (Strengths, Weaknesses, Opportunities, and Threats) analysis to assess Malaysian business development. It is supported with findings from the literature and secondary data. The relevant secondary data were collected from Bank Negara Malaysia and the World Bank.

Findings: This study shows that e-wallets in Malaysia have still not achieved their purpose but there is huge potential to do so. The SWOT analysis identified several strengths (e.g. financial incorporation, easy to access, protection and safety, simple for other accounts to connect to, product and consumer service management, quick to implement/administer), weaknesses (e.g. lack of infrastructure and the 'tapping' of devices already cornered by the mobile phone market, opportunities (e.g. eliminating fraud, better customer service, promotion/loyalty that can be built into customer experience) and threats (e.g. attacks from viruses, frequent inquiries whether multiple wallets can be used by clients, the concerns of reckless spending behaviour of the E-wallet users).

Research implications: This study is crucial for assessing the current situation and the prospects of e-wallets in Malaysia. This study also offers significant insights for policymakers and e-wallet service providers to develop appropriate strategies to enhance e-wallet services in Malaysia.

Originality/value: This paper is the first of its kind to integrate a SWOT analysis and the rapid development of the e-wallet market in Malaysia. Hence, the findings could broaden our knowledge on the fintech industry and enable firms to participate in the e-wallet market.

Keyword: Fintech; E-Wallet; Digital payment; Electronic payment; Malaysia

\section{Introduction}

The modern digital revolution conveyed by ubiquitous internet connectivity and the immense usage of mobile phones has created huge possibilities for payment systems to grow. One example is the emergence of sophisticated advanced payment apps, such as E wallets implemented on cell phones of consumers, provided by the growth of flexible payment providers that try to suggest more incentives to retailers and consumers, than banks have done before. (Kazan et al., 2018). The e-wallet is a transaction structure where an internet program or service permits clients to handle data in a central place linked to acquisitions, affiliation, loyalty and finance information. It is slightly similar to the physical wallet (Uddin \& Akhi, 2014). The e-wallet behaves like a regular one except that the money is digital and the phone has the e-wallet as an app. All that is required is to put funds into the e-wallet, and most applications in any case allow users to do so using credit cards, debit cards, or online bank transfers. Even if there is cash in the e-wallet, it can be used to pay retailers through a range of methods, including scanning a QR code, "press and pay" through the NFC feature of the handset, or with the corresponding physical card with certain e-wallets. Many e-wallets make it possible to send money instantly to friends who specifically use the e-wallet inside the app. 
Cashless transactions have now become extremely popular and the worldwide demand for ewallets is constantly increasing (Singh et al., 2020). Research shows that consumers seek a faster, cost- and time-effective technology for their daily personal financial transactions. For this reason, the e-wallet is considered an effective way to fulfil this need (Nizam et al., 2019). Eventually, people all over the world are now making the transition to a conventional payment gateway to e-wallet technology so that their transactions are faster. The security of this online wallet is protected by a distinct password and this wallet can be used to buy anything from small groceries to computers, flight tickets, luxury items online, etc. (Karim et al., 2020).

Jayaseelan (2017) states that payments are not the only thing those e-wallets can handle. They offer further extended services that are believed to create more value to its users. Some common features it provides are transfer of funds between individuals, credit card integration and patented magnetic strip technology. It also provides all the functions of today's wallet on one convenient smart card which removes the need for multiple cards. With each credit card purchase, identification is required, and if the card is altered, the card is fitted with a disabling tool. In addition, it offers a cheaper cost transaction process by removing the requirement for a middleman. Its efficient transaction processing gives markets the competitive edge for using this platform. It also opens up a new dimension to the payment systems for large markets and creates more or better business opportunities. Having all these advantages, consumers are shifting from traditional cash-based transactions to cashless payments hence producing value for all. Some of these have been fruitful, while others still fail to resolve the diverse challenges and prospects personified in the platform business process development models (Cennamo and Santalo, 2015).

The increased intricacy of frameworks and the requirement for normalization of the contributions of numerous services, for example, alternative payment platforms suggest that firms need to build up their skills and business abilities to deal with significantly more mind boggling projects that incorporate both intangible (services) and tangible (items) perspectives (Grönroos, 1997). Behind this intricacy, there is a fast advancement of technology, especially information technology (IT). This is driving the adjustment in business process improvement and includes the spread and efficiency of information, an emphasis on quality, and responsiveness, and adaptation to strategic planning, globalization, partnering, outsourcing, social and ecological accountability, and an adaptable client interface. Hammer and Champy (1993) characterized business process as "a collection of activities that takes one or more kinds of input and creates an output that is of value to the customer". With that in mind, Yaokumah, Kumah and Okai (2017) argue that it is not easy to completely shift from a cash-based to cashless mode of payment, since the former is a century-old transaction mechanism that is still strongly supported. Nonetheless the prospects for the e-wallet remain strong due to the increased popularity of e-commerce in recent years. Due to technological advances and people's increasingly hectic lives, consumers want the convenience of a fast, effective and effective payment system (Nizam et al., 2019). Research shows that e-payables opt for the transition from paper-based to e-payment systems, reducing the effort to deal with payable accounts (Grigg et al, 2014). This ultimately works as a cost-saving mechanism for the consumers and companies alike. From the business owner's perspective, another opportunity the e-payment system creates is future business prospects with existing clients. In this system, client data are stored in a secured and organised way which can easily be retrieved and used for further online purchase. This retrieval can be used for future product and service promotion as well (Chauhan, 2015). 
However, despite having a number of convenient features, there are disadvantages in the ewallet payment system. Growth is one of the major issues faced by many-sided platforms such as e-wallets, generating a critical mass of users and thereby unleashing the possibility for network influences (Hagiu and Rothman, 2016). Since e-wallets are used as channels in the wider ecosystem of financial technology (fintech), they are no exception (Kauffman and Ma, 2015; Milian et al., 2019). Niranjanamurthy et al. (2013) also states that the risk of fraud is huge in the e-wallet system, coupled with stealing, illegal control over someone's account. Moreover, the vendors not providing the required service may discourage consumers from using the e-wallet. So, it is clear that the e-wallet payment system has both good and bad points as a powerful alternative digital payment system. On the other hand, E-wallets reviews in Malaysia are scarce, Leong et al, (2021), Loh et al, (2021) and Susanto et al, (2020) all examined behavioural and usage aspect of the E-wallet customers regarding this new phenomenon however, there are hardly any studies that focus on this topic from the perspective business process development. Therefore, this study investigates the challenges and prospects of using e-wallet in business in Malaysia. Malaysia is an ideal country to research because fintech adoption in e-payment transactions are still low when compared to other countries. The Malaysian government started its initiative in developing fintech in 2011. This idea was part of the 10-year Blueprint Financial Masterplan to transform the country's financial system into a high value environment, and help Malaysia become a highly developed country by 2020 . Bank Negara Malaysia (BNM), the central bank of Malaysia, plans to create a cashless nation by 2020 , the key to this being mobile-based payments. However, over the last couple of years, so far only approximately 40 e-wallet licenses have been approved.

This study will benefit e-wallet users and providers, marketers and policymakers to understand the important features, prospects and challenges involved, so that they can improve the service quality of the e-wallet system. The findings will help guide policymakers and e-wallet service providers to develop appropriate strategies on how e-wallets can flourish in Malaysia.

\section{Literature Review}

E-wallet is a fintech tool; whereas fintech is defined as a technology utilised in multiple businesses such as books, transportation, telecommunications and finance-related products (Wikipedia, 2020). Scholars have generally adapted the definition of fintech defined by Financial Stability Board in which fintech is described as technology that enhances financial products and services. This process affects the financial market and traditional financial institutions regarding their processes, applications, products and services (Navaretti et al., 2018; Schindler, 2017). Meanwhile, the ever-increasing global demand for paperless payment systems has turned the mindsets of consumers to consider using e-wallets, and can the advances being made may change the dynamics e-wallet acceptance significantly (Shekhar et al., 2020).

Fintech is a combination of the terms 'financial' and 'technology'. Scholars have shown that Information technology (IT) has wielded significant influence on business structures, performance and business models (Venkatraman, 1994; Venkatraman, 2000). There are 5 levels that have proved to be revolutionary in the business model. Further analysis of the Business Process Re-engineering or Redesign (BPR) has found of these 5 levels, the first two levels deal with evolving technology and the next three levels saw this technology become a significant part of the insurance industry. The evolution of fintech started with fintech 1.0 (1866-1967) which was mainly about developing infrastructure in financial globalisation. Then fintech 2.0 (1967-2008) began with the first ATM installed by Barclays Bank in 1967 in the United Kingdom. Following this was fintech 3.0 (2008-current) which focused on fintech start- 
ups (Arner et al., 2015) and currently the world is experiencing fintech innovation 3.5 (Salampasis \& Mention, 2018).

\subsection{FinTech 1.0 (1866-1967): Analogue to Digital}

Fintech 1.0 was the first stage and it covered the period 1866-1967 with the focus being on global trading. This phase marked the establishment of global interconnections between banks and financial institutions. Infrastructure such as bridges and railroads were built to make commerce and trading activities faster and more efficient; it paved the way for what would happen in the future (Arner et al., 2015; Boamah \& Murshid, 2019). During this period the first trans-Atlantic cable and the first electronic fund transfer system was developed in the United States in 1866 and 1918, respectively. Furthermore, the famous Diner's club credit card emerged in 1950 and it enabled an initially small group of people to start using digital payments through credit cards.

\subsection{FinTech 2.0 (1967-2008): Refinement of Traditional Financial Services}

The second stage known as fintech 2.0 covered the years 1967-2008 and during this time the finance industry refined financial services and features associated with them. The first ATM was launched in 1967 and the digital finance world began. The world's first digital stock exchange for trading activities got started with NASDAQ in 1971. Fintech 2.0 enabled significant changes from traditional banking systems which turned into digital systems through the impact of advancing technologies. Many financial services activities now became digital systems such as stock market exchanges, bankers' automated clearing house services, payment systems such as SWIFT, etc. During this period, many other fintech services emerged such as online banking, mobile payments and PayPal. The internet got underway in the mid-1990s and e-commerce business models flourished especially in developed countries. At the same time, regulations on protecting fintech users were established due to the rapid growth of technology and fintech innovations. During this stage, financial technology received widespread acceptance throughout many societies, not just certain industries, banks and other financial institutions. Traditional banking systems were increasingly replaced by fintech innovations in the form of computerised and digitalised systems (Arner et al., 2015; Boamah \& Murshid, 2019).

\subsection{FinTech 3.0 (2008 - present): Democratising the Digital World}

Stage 3 which is known as fintech 3.0 is generally accepted as beginning in 2008 , when the fintech evolution led to new financial services and products. The global financial crisis of 20089 not only hugely disrupted and nearly destroy the global financial industry but also forced the developed countries to develop better finance/business models and more secure innovations. The finance industry now had to become more transparent due to consumers now being much more cautious about the information and services they received from banks and finance companies (Palmié et al., 2020). Bitcoin was released in 2009 and Alibaba introduced loans to SMEs on its e-commerce platform. Digital payments grew rapidly on in multiple platforms such as Google Wallet, P2P money transfer services and Apple Pay. At the same time, traditional banks had to deal with the competition generated by new fintech developments. 


\subsection{Fintech 3.5: Fintech Innovations}

The fintech revolution has led to a series of major and far-reaching changes, and now a plethora of financial services and products have led to new kinds of interactions in the finance industry and the consumer market (Salampasis \& Mention, 2018). Fintech 3.5 is defined as a fast growth phenomenon and it targets young people equipped with mobile devices/phones. Consumers' usage of fintech and the behaviours involved mean that trust and convenience go hand-in-hand due to the rapid developments in fintech innovations. Many businesses are looking for more opportunities in fintech start-ups to improve their profits and create a new business model. The private sector is hugely involved in this process, to diversify and grow business. Scholars contend that finance-related innovations and sustainable development are understood by customers because they offer better financial services and products, and legislation or regulations reflect this reality (see Salampasis \& Mention, 2018; Schindler, 2017; Kerényi \& Molnár, 2017).

At the same time, fintech innovations can be categorised into three types, namely, surface innovation, genuine innovation and foundational innovation. The first level or surface innovations do not fundamentally change the nature of financial services and products, which mean the users and providers of services basically remain the same. For the second level of genuine innovation, new products and services do lead to more significant changes such as the concept of life insurance. The third level or what is known as foundational innovation marks the most significant changes, for example completely new infrastructure and other financial systems that have radically reshaped the finance system (Schindler, 2017).

\subsection{The Emergence of E-Wallet}

Fintech innovations and fintech starts-up are now very ubiquitous in the world's developed market economies (Chiu, 2017), rising from a total value of US\$1.2 billion in 2008 to US $\$ 22.3$ billion in 2015, according to data from Multinational Professional Services Network (KPMG), 2016. The United States became the largest fintech market in the banking/finance system (Haddad \& Hornuf, 2019), but China is closing the gap with the success of Alipay and Yu'E Bao (Chen, 2016). Venture Scanner (2017) reported that the US invested US $\$ 80.4$ billion in fintech start-up innovations in 64 countries which in total involved 1,537 companies at the final quarter of 2017. In developing countries such as Africa (Kang, 2018), South Korea (Choi et al., 2020), Kenya (Lashitew et al., 2019), Pakistan (Shaikh et al., 2017), Indonesia (Tan et al., 2019) and Malaysia (Tun-pin et al., 2019) significant fintech innovations and business development are now occurring those countries' financial services industry.

At the same time, the growth in people's mobile phone bank accounts has reached half the world's population and this means in effect $49 \%$ of users are connected worldwide (GSMA, 2018). Similarly, continued growth of fintech reached 525 million adult users who adopted mobile money services in 2017. It is evident that fintech innovations have occurred in both developed and developing nations. Fintech facilities provide high value financial services in the global market and offer greater business opportunities. Although fintech has generated many services and products that are competing, governments are increasingly regulating or legislating the industry due to the devastating outcomes of the global financial crisis. Fintechdriven transformations have meant that the traditional business models are now integrated into, or replaced by, modern banking industry and mobile banking policies and services. Scholars studied that the impact of digital payment has fundamentally changed the finance industry in terms of cost efficiency and superior quality (Kerényi \& Molnár, 2017; Gomber et al., 2018). 
Fintech mobile phone payments not only make online payments possible but also shopping and others payment needs that are low cost, and quick and easy to access (Hung \& Luo, 2016; Gomber et al., 2017).

As stated earlier, when developed countries began their fintech revolutions, developing countries would inevitably be affected. Rapid growth of fintech start-ups and a very high rate of adoption in digital payments system was evident in Indonesia, according to the Bank Indonesia's findings (Tan et al., 2019). Similarly, the fintech innovations in Hungary greatly changed the finance sector and its services, especially in payments schemes when bank-card payments and contactless payment transactions were introduced (Boamah \& Murshid, 2019). Digital payments grew from $18.6 \%$ of bank card transactions to $19.1 \%$ between 2014 and 2015 with a total of 300 million transactions every year according to the Central Bank of Hungary (Boamah \& Murshid, 2019). The banks enjoy a greater advantage in building trust between themselves and customers due to better security systems compared to others financial institutions (Zhiming et al., 2013). Fintech may have put pressure on the traditional banking system but banks can reduce the cost of borrowing and this widens the customer base (Navaretti et al., 2018). Meanwhile, the impact of fintech payments in Taiwan is noticeable in essentially two categories, these being point of sales payment and third-party payments which are offered online, offline and online-to-offline facilities. The Taiwanese legislation known as "The Act Governing Electronic Payment Institutions" was implemented to supervise third-party payment institutions with reference to fintech innovations (Hung \& Luo, 2016). Clearly, banks have their own policies regarding business activities that need to take fintech developments into account, and this could have implications for emerging market economies such as Malaysia.

Fintech innovations on mobile devices such as ATMs and smartphones are now the major payment methods in southern Asia, and these have been made possible by the fintech revolution. Furthermore, the adoption of digital payments usage in the past year for developed countries allocated $44 \%$ compare to $12 \%$ in developing countries, according to global index 2017 (Hess, 2017). Today, China has become the leader of fintech given that the most successful digital payments devised in that country are Alipay and Wechat Pay. They offer services to more than 100 million people despite Paypal still being dominant in global business (Chen, 2016). Obviously, China has huge potential growth in making digital payments able to reach a global market. Moreover, it is important to note that security problems that can lead to account losses or account hijacking among debit cards and bankcards, are much lower in China's systems. Aliay's fraud rate is under $0.01 \%$ while that of Wechat Pay is under $0.02 \%$. These are much lower when compared to the US market.

In Malaysia, Chew et al, (2020) explored the entrance of Chinese-based Alipay's cellphone payment innovation into Malaysian business sectors. This passageway occurred around mid2015 and was first of its sort possessed by owned by a foreign company. The acknowledgment of such innovation was made conceivable by Bank Negara Malaysia and few other local banks who considered this to be a chance to connect the business sectors of the two nations. From that point forward, businesses across the nation acknowledged Alipay shows by showing notices on wall and door stickers and table cards. This sort of E-wallet was also broadly utilized by the Chinese travelers visiting in Malaysia which considered local people to effortlessly acknowledge it thus appealing to their foreign customer's needs. On the other hand, the public authority of Malaysia also urges local people to utilize the e-wallet platforms. As referenced by the Minister of Finance, the Malaysian government gives RM30 subsidy to all Malaysian individuals reached 18 or above to take an interest in the e-wallets framework. The motivator was made to urge Malaysian people to take an interest in the e-wallet framework. During a 10- 
month time span from January to October 2019, insights by Central Bank of Malaysia (BNM) showed that the exchange value for e-cash reached around RM13.9 bln with an exchange volume of 1.72 billion, outperforming the RM11 billion figure that was recorded for the entire of 2018 out of 1.92 billion exchanges (Andrew et al., 2019). Therefore, the demand for the ewallet framework is expanding to help the Malaysian government program in advancing this sort of digital money.

The ever increasing global demand for paperless payment systems has changed how consumers think about the e-wallet (Shekhar et al., 2020; Singh et al., 2020). The origin of the e-wallet concept was in the mobile phone payment system which is now widely accepted as an alternative payment method for both consumers and traders. Originally, the barter system was one in which people exchanged goods for goods but with the passage of time this system was replaced by paper currencies like the US dollar or British pound (Das Nair \& Landani, 2020). In the $20^{\text {th }}$ century the world of business started employing plastic money like debit and credit cards which reduced cash-based transactions. The boom in smart phone technology coupled with the internet revolution means that new forms of payment such as those on mobile phones make the e-wallet payment platform possible (Teoh et al., 2020). Currently, there are various types of e-payments that provide real-time and world-wide cashless transaction facilities to consumers and businesses.

One important aspect of electronic currency is that it has no or vary low production cost. Banknotes and coins are not produced from precious metals but technically they have their own cost in terms of manufacturing, although this cost does not equate the quantity of products that can be purchased with them with its actual value (Assenmacher \& Krogstrup, 2018). However, e-payments have improved the efficiency of financial systems in terms of transaction cost reduction, liquidity improvement and effective allocation of financial capital. There are, however, arguments that the adoption of e-payments might have some policy issues from a central bank's perspective due to its concerns on how such a payment system should function (Gupta \& Gupta, 2013.). It is further argued that e-payments might destabilise the money multiplier and decrease the demand for physical money. Using e-money as a means of payment is likely to build near-substitutes for physical cash that would increase the development of narrow money or even replace the demand for conventional bank deposits and other liquid deposits. There is vast literature that worry standard pattern of business process improvement. For instance, Becker et al. (2011) gives a point by point outline of techniques and instruments for the cycle plan that compares to different works devoted to process development. On the other hand, when you take a gander at the literature on E-wallets in Malaysia, Leong et al, (2021) inspected the aim of utilizing cellphone payment services among Malaysians in Sarawak district, also Loh et al, (2021) investigated the reasons behind the slow uptake of mobile payment from a switching intention (SI) perspective while Susanto et al, (2020) examined the determinants of clients' social aim and genuine use conduct of e-money services in a transition financial settings in Malaysia. Therefore, most of these studies focus on behavioural and usage aspect of the E-wallet customers regarding this new phenomenon however, there are hardly any studies that focus on this topic from the perspective business process development. Despite the fact that the traditional way to deal with business process development has its benefits, it sometimes falls short for most of all business conditions, specifically, it may not be appropriate for the situations with a serious level of dynamism therefore, this study looks into challenges and prospects of using the E-Wallet as business process development in Malaysia thus filling the gap in the literature. 


\subsection{Process of Using E-Wallet in Business Development}

Traditional banks implement payment processing services either online or offline. Payment services provided by local banks have the highest usage by customers for reasons of convenience and flexibility. Customers need to register and hold an account for such things as credit cards or debit cards which are linked to their bank accounts. When transactions are made by the customers such as a purchase or any other transaction, the merchant will request payment clarification and information so that the transaction is approved. Such transactions can only be done through the verification of a local bank in order to transfer the funds to a specified location such as retail shop, payment merchant and another financial institution. Meanwhile, customers may make a consistent payment to any financial institution without directly transferring funds from the users' pocket, through a simple 'click' of a button.

According to Kang (2018), digital payments can be made directly or indirectly to the financial institutions, made possible by fintech digital payment platforms and payment facilities. Although users still prefer to use traditional methods of payment in the local banks due to good security and private information protection services, there is more advantage in using fintech digital payment systems. Traditional payment services only can be done according to what the financial institutions state, so their platforms and policies are to some extent limited. For example, users generally own several cards or accounts for making multiple transactions. Digital payments allow users to make multiple transactions that are not specific to any financial institution or dependent on a single platform. Digital payment can be registered with any financial institution by using technologies that can make numerous transactions independently. Users can easily make a transaction by selecting any digital payment service provided by a fintech technology.

The e-wallet is a high-tech, cashless network service that allows users to shop online. As long as there is a registered account and login name, anyone can use the e-wallet service anytime and anywhere with a password. All shopping will be delivered to the indicated place and destination. It can be seen that e-wallet consumers now have access to a fast, convenient, hightech, convenient tool, for example global online shopping (Salah Uddin \& Yesmin Akhi, 2014). After completing the specific registration procedure, anyone can deposit money into the ewallet account and can activate its functions. The electronic wallet is linked to a person's bank account.

\section{Research Methodology}

This study employs a systemic literature review to assess the literature on e-wallets in Malaysia, but not much has been published on this important phenomenon. For this reason, the study examines the e-wallet from the perspective of Malaysian business using a SWOT (Strengths, Weaknesses, Opportunities, and Threats) analysis. It is based on what the available literature and secondary data have reported. The relevant secondary data were collected from Bank Negara Malaysia and the World Bank. SWOT analysis is a valuable method for helping managers define operational and environmental variables, so that strategic plans can be put in place to determine the appraisal of an enterprise, a strategy, or a business operation. SWOT analysis is an easy but effective method to exploit the resource capabilities and vulnerabilities of an enterprise, its business prospects and external risks that could occur in the future. 


\section{Analysis}

\subsection{Current E-Wallet Usage in Malaysia}

Fintech institutions have financial services that are combined with recent or the latest technology. A breakdown of fintech players' operations shows that payments and e-wallet segments play an important role in Malaysia's fintech, amounting to $20 \%$ and $19 \%$, respectively. Other players are Regtech (6\%), Insurtech (8\%) while the other lending, wealthtech, blockchain and remittance systems amount to 7\% (Figure 1). It can be stated here that the e-wallet has emerged as an important tool in fintech.

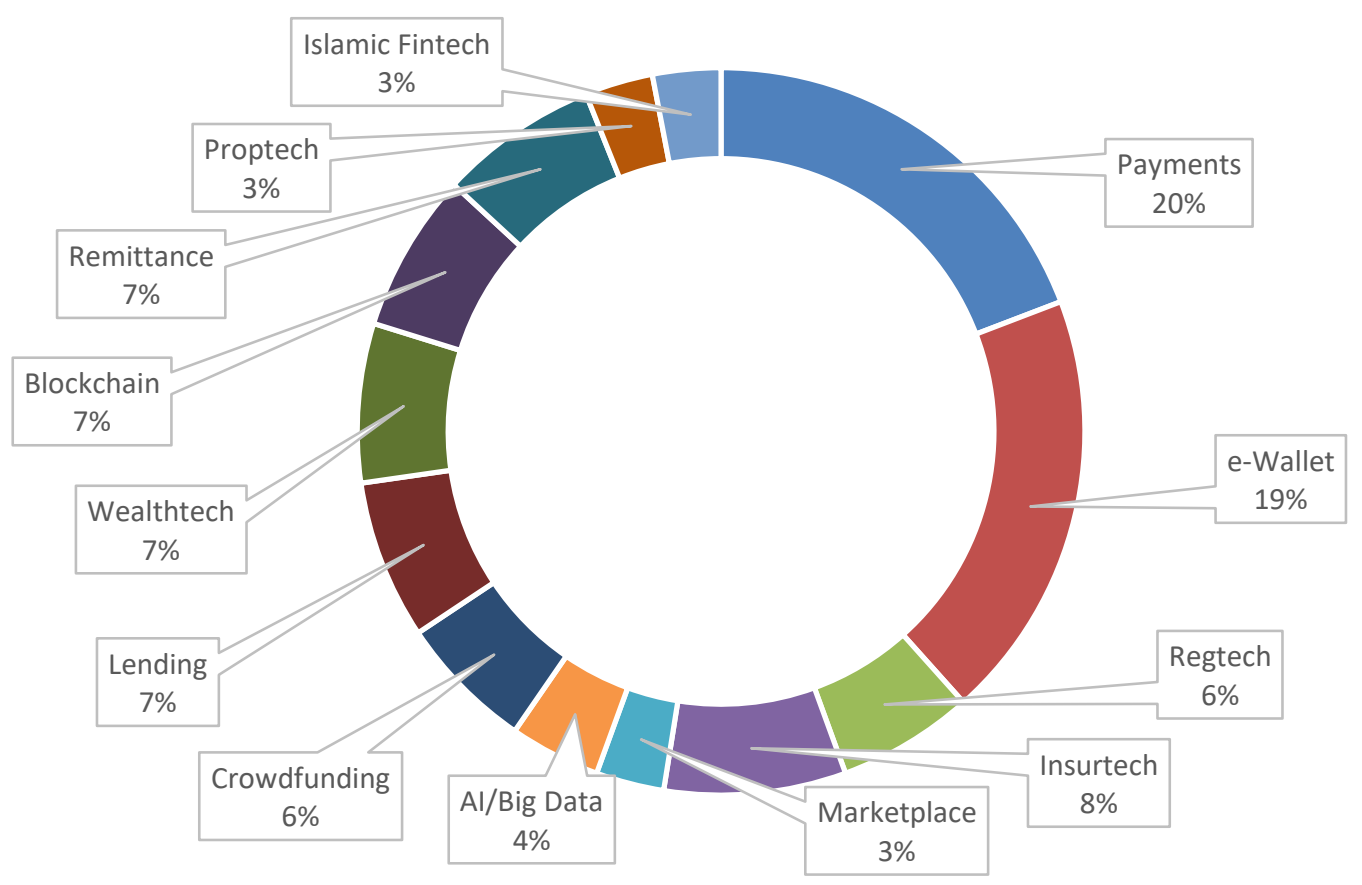

Figure 1: Breakdown Fintech Players in Malaysia

Sources: Fintech Malaysia, 2019

Due to the rapid growth of e-wallet systems in Malaysia, there are in total 48 non-bank e-money issuers listed under Bank Negara Malaysia (Bank Negara Malaysia, 2011) and they occupy $19 \%$ of the fintech industry according to a report in Fintech News Malaysia (2020). The ewallet start-up market has become a crucial aspect of the Malaysian economy. The Central Bank of Malaysia formulated a Financial Sector Masterplan (FSMP) in 2001 to guide and help in the financial development of the country. The transformation of the finance sector since then has played as important role in supporting local economic growth. To exploit this potential, the government put in place some policy measures to boost public awareness of the cashless transaction system and its advantages. For example, the Bank Negara Malaysia reduced the fees involved in instant e-payment by as much as RM5,000, and also increase the chequerelated processing fees (Bank Negara Malaysia, 2011). Moreover, the government allocated a RM30 payment to e-wallet users out of the national budget for 2020 to boost e-wallet use (Teoh et al., 2020). It should be noted that the Financial Sector Blueprint aim is to transform Malaysia into a high income and developed country by 2020 which is set out to increase the digital payment transactions from RM22 to RM200 per capita. This represents a big motivation to develop e-wallet use throughout the country. The e-wallet provides consumers with a fast, 
convenient, high-tech, convenient method that can utilised anytime, anywhere, especially given the upsurge in global online shopping.

The fintech revolution's rapid growth has triggered a raft of government legislation and regulations to protect customers' data and financial information disclosure issues. Malaysia Securities Commission (SC) started supporting the development of fintech in Malaysia in 2014, so that it became the first Asian country to establish a regulatory framework on financial services and products (Tajudin \& Musa, 2018). Local governments in Malaysia not only focus on the booming financial development in their areas, but also on how to protect the interests of consumers to ensure the healthy and transparent functioning of the finance industry. All ewallet vendors must be licensed to do so according to the BNM and SC guidelines. According to Bank Negara Malaysia ${ }^{1}$, there are 48 non-bank e-money issuers listed under Bank Negara Malaysia. The major Malaysian e-wallet merchants are summarised in Table 1 below.

Table 1: E-wallet Types and Mechanisms in Malaysia

\begin{tabular}{cclc}
\hline E-wallet & Backed up By & \multicolumn{1}{c}{ Usages } & \multicolumn{1}{c}{ Merchants } \\
\hline Boost & Axizta Group & 140,000 touch points covered in stores & Watson, Tealive, \\
& & in Malaysia, accepting UnionPay Cards, Giant, KK Super \\
& & Pay DBKL's car park and Astro, & Mart \\
& Syabas and Telekom bills
\end{tabular}

GrabPay Grab

Used to purchase food, shopping,

KFC, Legoland, paying for taxi rides, allow mobile phone credits to be topped up, pay Boost, Jaya Grocer, Celcom, Digi, Maxis, U Mobile and Family Mart

TuneTalk, allow Maybank customers cross-platform use.

Touch'n Go Alipay, Touch'n Covers 150,000 merchants nationwide, Mydin, Tesco, pay tolls, purchase items on Apple Giant, Diamond, Store and iTunes, pay for street parking, Laza, Watson, taxi rides and food delivery services, Converse bus tickets, KLIA Express and KLIA Transit tickets

Razer Pay Razer Inc 1,000 online merchants participate with Starbucks, F.O.S Ambank, Banks Islam, CIMB, Hong KK Super Mart, Leong Bank, Maybank, Public Bank, Burger King, 7purchasing games eleven, Fashion Valet, JD Sports

Wechat Pay Tencent Group Enable local currencies to be paid KK super Mart outside of China, participate with Ambank, Hong Leong Bank, iPay88, MOL, Revenue Monster, KK Super Mart, purchase bus tickets, withdraw money

MAE Maybank Available to 200,000 merchants, purchase movie tickets

Jaya Grocer, Aeon, TGV Cinema, Krispy Kreme, 
Watson, Mydin,

McDonald's,

Franciso Coffee

BigPay $\quad 70 \%$ AirAsia In tandem with physical MasterCard,

Accepted 40 million

$\begin{array}{ll}\text { online purchase, withdrawing funds } & \text { merchants } \\ \text { from ATMs } & \text { worldwide except }\end{array}$

North Korea and

Israel

Sources: Muslimin, 2020

Although digital payment channels are still in the early development stage, this scenario is changing gradually. According to the banks' perspective, payment services are the biggest concern of customers. Therefore, fintech is crucial and the most challenging aspect is to make it more efficient and exciting. Most e-wallet companies in Malaysia are still offering various freebies and cashbacks to customers because in Malaysia $92.5 \%$ of the payments are still cash based. However, e-payments are increasing at $9 \%$ annually thanks to different reward-based initiatives (Nizam et al., 2019). The market's top e-wallets like Touch'n Go, Grab and Boost have now had millions of downloads. Figure 2 depicts the top e-wallet rankings in Malaysia, where the first choice of Malaysians is GrabPay which is followed by Touch n'Go and Boost. The time period covers mid-2018 until the third quarter of 2019.

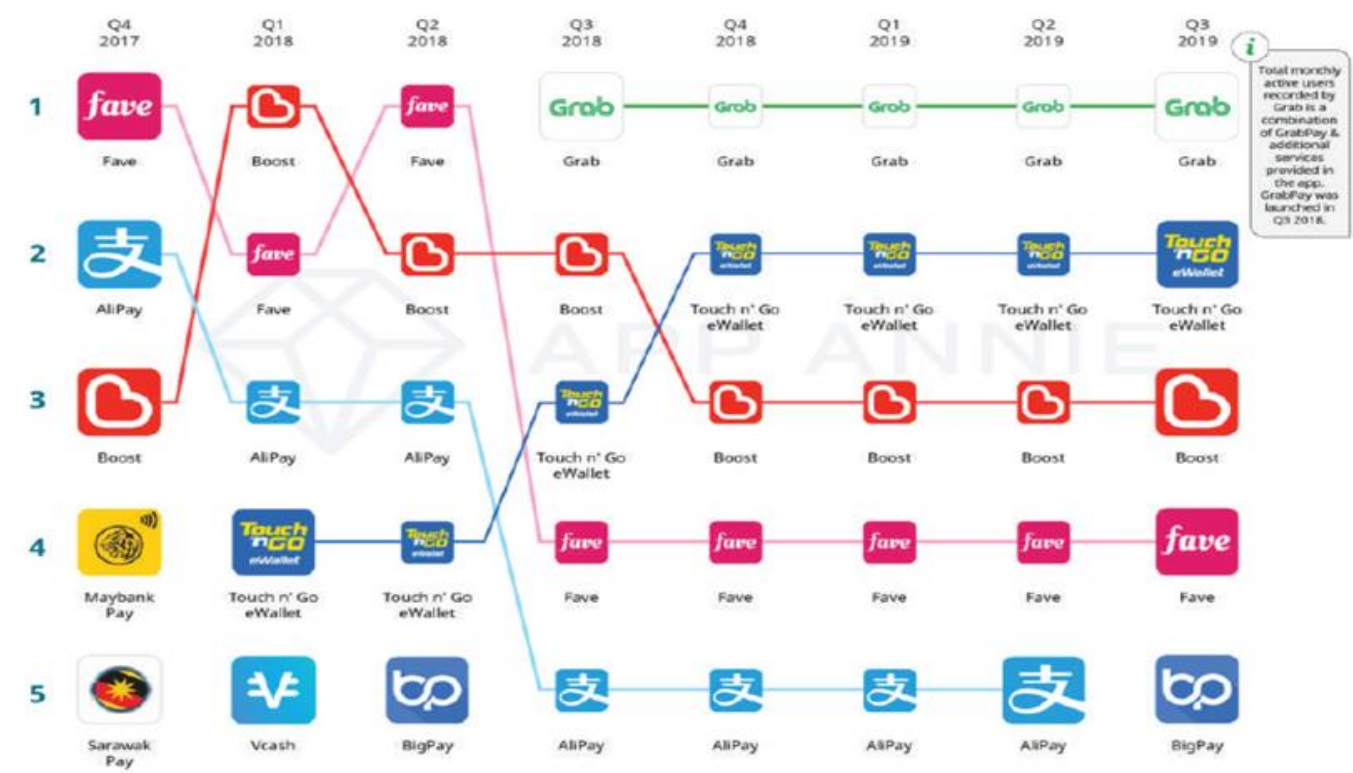

Figure 2: E-Wallets' Ranking in Malaysia Sources: Chew, 2019

Looking at the profiles of Malaysian e-wallet users, it shows that in the 25-34 age group, ewallets are more widely utilized with a solid proportion of e-wallet users even in the 35-44 age group at 25 percent (Figure 3). It is also clear that the use of e-wallets is more widespread among those who are in PMEB (Professionals, Managers, Executives and Businessmen) positions, because they might be more aware of technological trends and are able to take advantage of using e-wallets. It is also noticeable that the e-wallet users have marginally higher income than non-e-wallet users. 


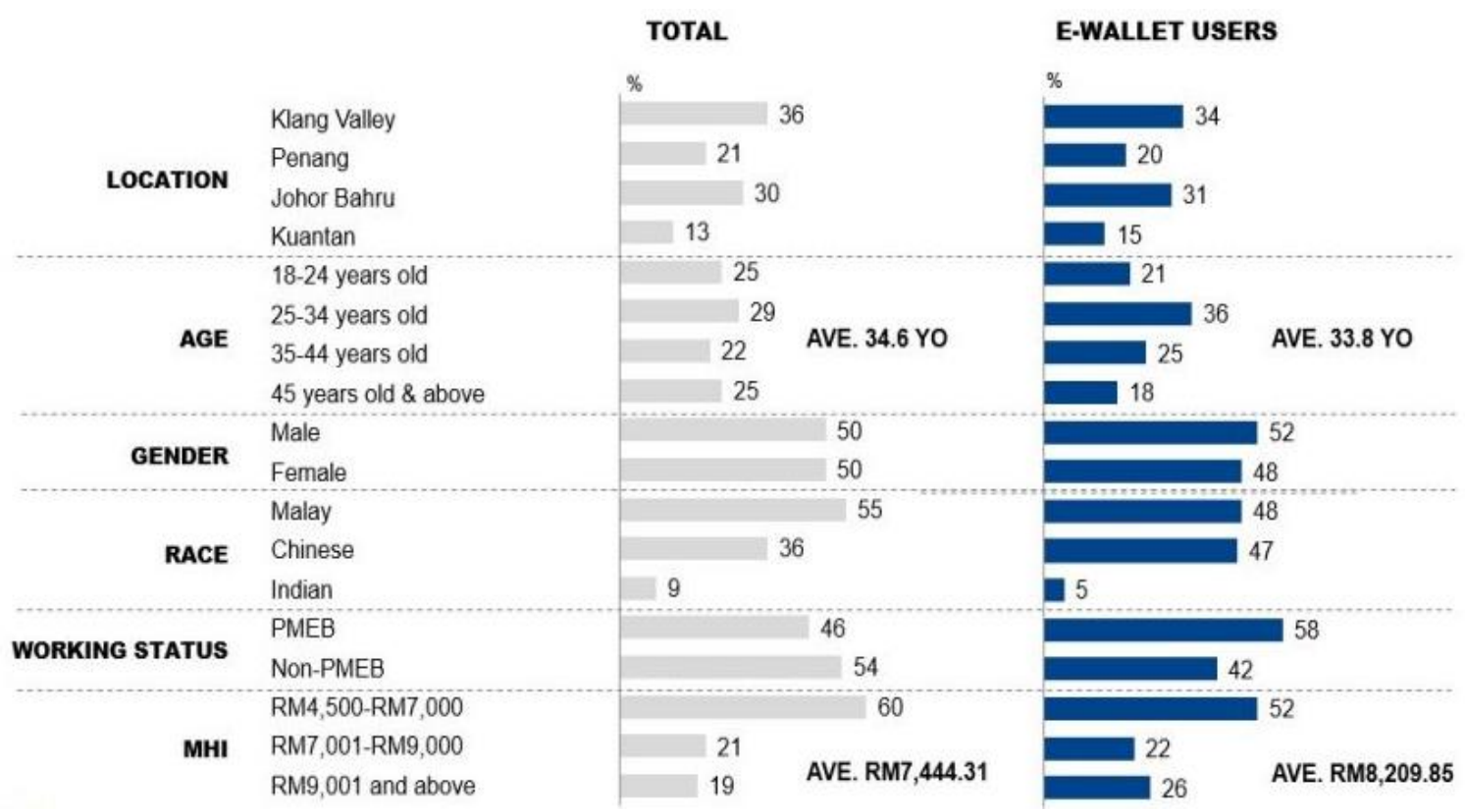

Figure 3: E-wallet Users Profile in Malasyia

Source: OPPOTUS, 2019

\subsection{SWOT Analysis for Using E-Wallet in Business Scenarios}

SWOT analysis is a technique for assessing four aspects - Strengths, Weaknesses, Opportunities, and Threats. Table 2 summarises these four themes for using e-wallet in Malaysian business scenarios.

Table 2: SWOT Analysis Matrix

\begin{tabular}{|c|c|}
\hline Strengths & Weaknesses \\
\hline $\begin{array}{l}\text { - Financial consolidation of accounts. } \\
\text { - Easy to access. } \\
\text { - Protection and safety. } \\
\text { - Simple for other accounts to connect } \\
\text { to. } \\
\text { - Product and consumer service } \\
\text { - } \text { management. } \\
\text { - }\end{array}$ & $\begin{array}{l}\text { - Lack of infrastructure. } \\
\text { - Already cornered by the mobile } \\
\text { phone market } \\
\text { - Users need an electronic wallet to } \\
\text { have a charged device to operate } \\
\text { it. } \\
\text { - Depends on the services made } \\
\text { available by e-wallet providers }\end{array}$ \\
\hline Opportunities & Threats \\
\hline $\begin{array}{l}\text { - Stop fraud. } \\
\text { - At the point of sale, it will offer better } \\
\text { customer service. } \\
\text { - Promotion/loyalty can be built into the } \\
\text { experience. } \\
\text { - Make shopping easier }\end{array}$ & $\begin{array}{l}\text { - Attacks by software viruses. } \\
\text { - Questions arise whether multiple } \\
\text { e-wallets can be used by clients. } \\
\text { - the concerns of reckless spending } \\
\text { behaviour of the E-wallet users }\end{array}$ \\
\hline
\end{tabular}

Strengths: There are certain strengths in the consolidation of accounts, and it is easy to access the apps and payment platforms. One 'click touch' on our phones can result in a transaction between a seller and customer. The most important thing is the protection and safety of the data 
and a customer's privacy. All online platforms now have a strong security and protection system to secure consumers' data. This technology makes it simple to access other account and for that reason customer service and product management must operate at their best at all times. Over the past few years, mobile wallets have become more popular and can be used at most stores that accept cards as a payment option. While there are still some sites that use older processing systems that restrict access to some goods or facilities, the number of stores offering access to purchases in this way continues to grow every year.

Weaknesses: Weaknesses of the e-wallet include lack of infrastructure whereby not all places or neighbourhoods can use it, so they would rather use cash then use this mobile app. This will not be convenient for those people who already and every day employ the e-wallet for transactions. Although an electronic wallet allows more flexibility for certain users, it does not totally remove the need to bring anything with them. If they do not have an individual to engage with on their mobile account, then they cannot complete a transaction. For that reason, customers are required to take a typical wallet or purse with them everywhere because these wallets do not store their ID or other important items. Another weakness is that individuals are already part of the mobile phone market, and for e-wallets to work they must upgrade their phones all the time. If they fail to do this, then customers will face problems with the app on their phone. Moreover, it still requires an internet connection and a type of mobile phone that can support the e-wallet app (De Luna et al., 2019). Another drawback is that users always require a charging device on them so that the electronic wallet can operate. Users do not need to worry about how much battery life is left on their phone when they carry a traditional wallet.

Opportunities: Regarding opportunities, this technology makes it possible to improve customer service when the sales are carried out efficiently. Providers or vendors of e-wallets can gain the trust of customers when customer service is good. More than that, they can enhance the loyalty of the customer and vendor to the app. Rather than cash or cheque, electronic wallets offer incentives to encourage consumers to think that for certain purchases, they are better for such things as fuel, food, or travel, or discounts. Some companies may also work with their ewallet platforms to offer specific discounts. So without changing their spending habits, users have the potential to save money. They can help manage people's spending patterns according to the desired electronic wallet. Some can produce reports that display particular spending categories for them. To guarantee that they do not spend more than they should, they can even delegate a budget to a particular product or service. However, if they have an expensive item to buy, they should be able to disable this transaction, so that they have enough cash to make that purchase and only at that price.

Threats: Technology is at the mercy of cyber security issues such as cyber-attacks. e-wallet can put an end to fraud or other people's attempts to steal a user's data and then sell it to a third party. Moreover, e-wallet has two kinds of threats attached to it. First, someone's smartphone or mobile device's security depends on the settings that person chooses. If users do not have a password protecting the device, someone might steal their device and access the money from the bank account or credit card. There are definite security benefits that make an e-wallet a useful technology, although to maximise them, it requires responsible management of it. There is also the great risk of being attacked by software viruses which can disable apps. Second, this type of technology can cause reckless spending behaviour by users, and simply encourages some individuals to struggle with their spending patterns; when money is electronically-based instead of a physical object then a person lacks a sense of its real worth. If they are still struggling with a traditional wallet to sustain a budget, then an electronic wallet could make 
the problem worse. Lastly, it is an issue whether several wallets can be used by one client, and this is a threat that has not yet been answered.

\subsection{Prospect of Adopting E-Wallet in Malaysia}

It can be stated that the e-wallet has significant prospects in Malaysia. In a cashless environment people can pay bills with their e-wallet rather than paper currency, which can lower the cost of paper currency management. There is no need to print money and hence, this can reduce the circulation of paper currency in many places through banks and ATMs. Therefore, all expenses of paper currency management can be avoided by switching from a cash-driven economy to a cashless economy. Moreover, transaction hours can be shortened because in a cashless environment transaction can be done with only a few clicks. Also, a company can develop new products that meet the preferences of customers based on their datadriven consumption patterns and preferences. This reduces the time required for investigating consumers' preferences significantly.

According to the BNM, the usage of e-money has witnessed a huge increase from 921.8 million with a total value of RM3.4 billion for 2012, to 2,093.7 million with a total value of RM18.2 billion for 2019. At the same time, according to the Bank Negara Malaysia, the finance industry has contributed an average growth of $7.3 \%$ annually of real GDP. This is expected to increase to $10-12 \%$ in 2020 . Although Malaysians still generally rely on cash-based facilities and transactions, e-money has grown substantially over the last 10 years and will continue well into the future.

Table 3: Payment Instruments in Malaysia

\begin{tabular}{|l|l|r|r|r|r|r|r|r|r|}
\hline Mil/RM bil & 2012 & 2013 & 2014 & 2015 & 2016 & 2017 & 2018 & 2019 \\
\hline \multirow{2}{*}{ Credit card } & Volume & 325.3 & 332.4 & 345.7 & 359.6 & 383.8 & 406.5 & 447.1 & 510.1 \\
\cline { 2 - 10 } & Value & 94.1 & 99.7 & 105.5 & 112.7 & 118.5 & 125.6 & 135.2 & 143.8 \\
\hline \multirow{2}{*}{ Charge card } & Volume & 4.1 & 4.0 & 4.4 & 4.2 & 4.1 & 4.7 & 5.2 & 6.2 \\
\cline { 2 - 10 } & Value & 6.5 & 7.2 & 8.6 & 8.9 & 9.7 & 11.0 & 12.5 & 13.1 \\
\hline \multirow{2}{*}{ Debit card } & Volume & 36.0 & 49.4 & 68.7 & 89.7 & 107.6 & 162.2 & 245.7 & 371.0 \\
\cline { 2 - 10 } & Value & 8.6 & 11.5 & 14.8 & 19.8 & 22.6 & 29.8 & 40.3 & 52.4 \\
\hline \multirow{2}{*}{ E-money } & Volume & 921.8 & $1,046.7$ & $1,175.0$ & $1,384.7$ & $1,663.2$ & $1,861.7$ & $1,920.4$ & $2,093.7$ \\
\cline { 2 - 10 } & Value & 3.4 & 3.9 & 5.3 & 6.0 & 7.7 & 9.1 & 11.0 & 18.2 \\
\hline
\end{tabular}

Sources: Bank Negara Malaysia, 2020

Moreover, Malaysia has experienced relatively steady GDP growth from 2012 to 2018 (Figure 4). Economic progress has enabled people to enhance their purchasing power and thus their consumption of goods and services. In a cashless economy, the willingness to purchase plays an important role and its increase can push up the ownership of e-wallets. Economic progress might encourage the government to increase investment in infrastructure related to electronic transactions. As digitalisation creates a financial revolution, the promotion of e-wallets will provide enormous opportunities for Malaysia to expand its economy. 


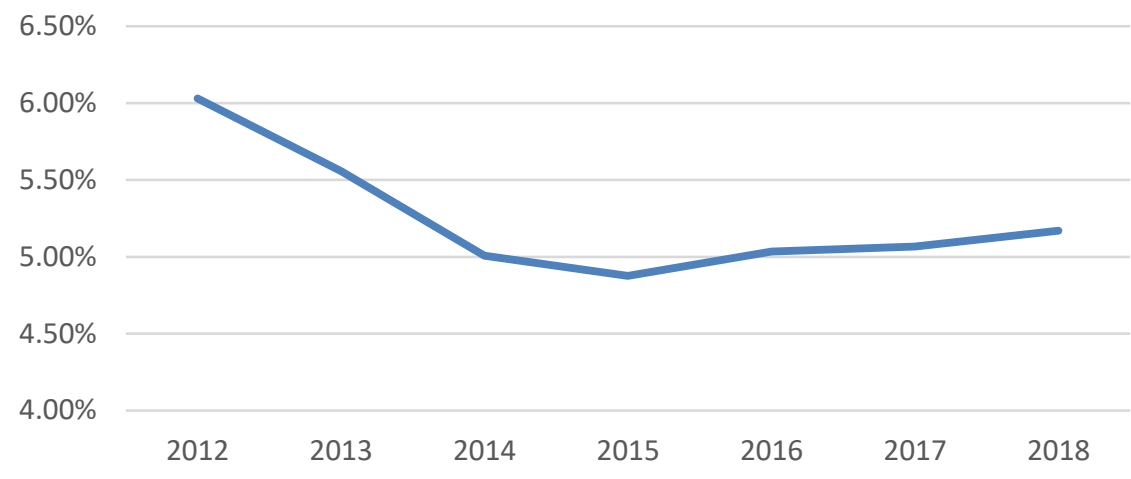

Figure 4: Annual GDP growth Rate in Malaysia Source: World Bank, 2018

According to the World Bank, a survey it conducted on fintech adoption every 3 years, found that Malaysia's mobile phone account holders rose every year from 2014 to 2017 (Figure 5). Most holders are the young adults, aged 15 to 24, who are followed by those in the workforce group, who are also male and on high incomes group. All types of mobile phone account holders have grown by more than $300 \%$ in the last 3 years. Consequently, there is much opportunity for fintech and the e-wallet industry to develop in Malaysia.

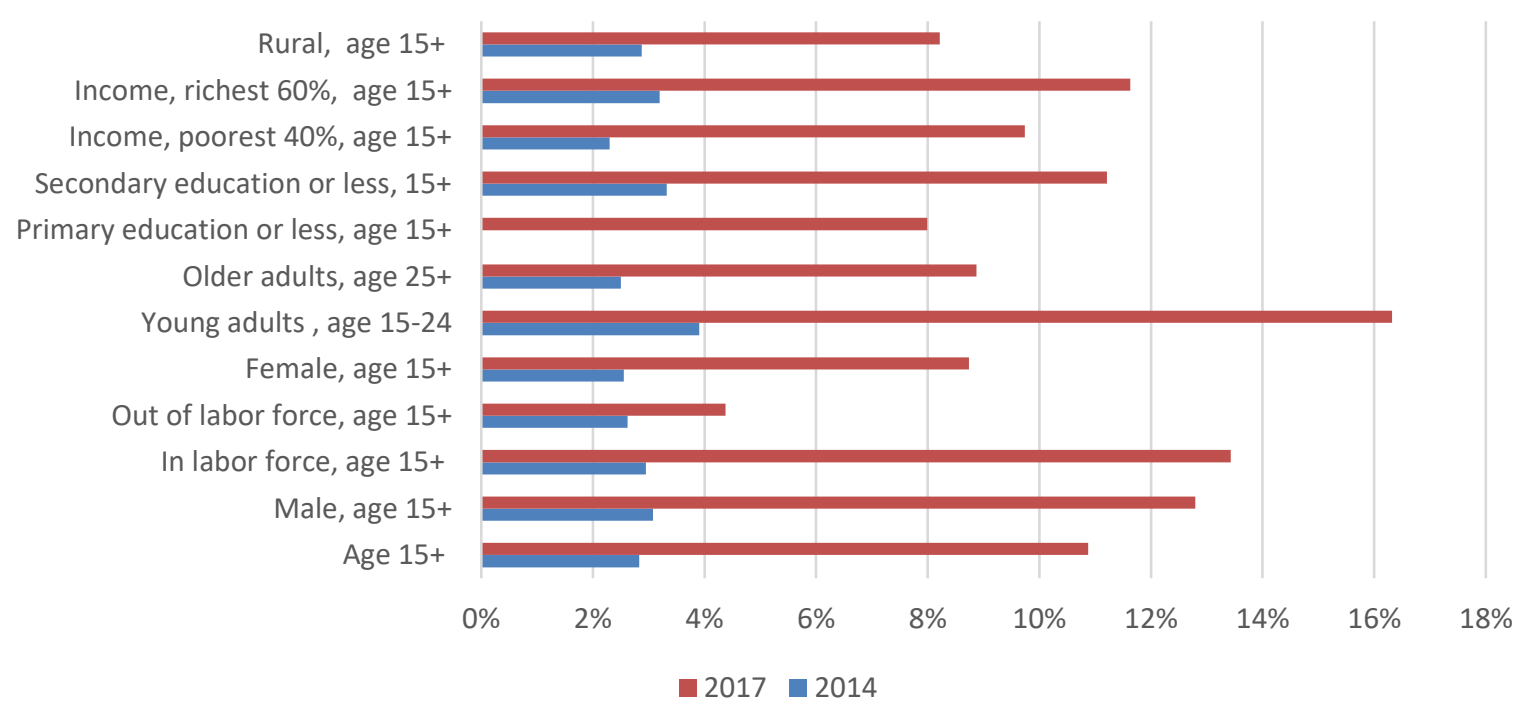

Figure 5: Malaysia's Mobile Account Holders in 2014 and 2017

Source: World Bank, 2018

Another big prospect for the Malaysian e-wallet lies in the country's increasing population. Malaysia's current population is 32.6 million but the growth rate is very high (Table 4). An increase in the population creates more demands. At the same time, Malaysia is transforming into a digital state and the numbers of smartphone and internet users have risen every year since 2012. This is expected to propel the use and acceptance of e-wallets in the future.

Table 4: Population Growth, Smartphone Users and Handphone-Internet Users in Malaysia

$\begin{array}{lllllll}2012 & 2013 & 2014 & 2015 & 2016 & 2017 & 2018\end{array}$




\begin{tabular}{|c|c|c|c|c|c|c|c|}
\hline Population (million) & 29.07 & 29.47 & 29.87 & 30.27 & 30.68 & 31.11 & 31.53 \\
\hline $\begin{array}{l}\text { Smartphone users } \\
\text { (\% of total phone } \\
\text { users) }\end{array}$ & 26 & 37.4 & 53.4 & 52.3 & 68.7 & 75.9 & 78 \\
\hline $\begin{array}{l}\text { Internet users in } \\
\text { smartphone (\% of } \\
\text { smartphone users) }\end{array}$ & 68.8 & 78.5 & 90.1 & 92.4 & 94.8 & 94.6 & \\
\hline
\end{tabular}

Source: World Bank, 2018

\section{Discussion}

The consumer market in Malaysia is changing and in a context where the economy is becoming an increasingly e-commerce-type system. It was noted by the United Nations that the majority of consumers in Malaysia - 29.6\% under the age of 15, 65.4\% between 15-64 years old, and 5\% above 65 years of age - are still using cash for their transactions (Nizam, Hwang \& Valaei, 2019). Issues of why Malaysians have not adopted the e-wallet opens up the opportunity to develop it so that it is more user-friendly and acceptable.

Despite the prospects for developing the e-wallet in Malaysia having much potential, it is observed that the use of e-wallet is still insignificant due to its technology-based functionalities. A mix of educated or less educated people in Malaysia fail to understand the functionalities of the e-wallet and other electronic payment systems. For this reason, they tend to avoid using this platform. Users cannot fully understand and accept the complex process of electronic payments. Due to their lack of adequate knowledge on how to use electronic payment gateways, they are vulnerable to fraud and theft. In Malaysia the dynamics of using credit cards has changed with the increased use of smartphones and the internet. This has fostered the development of the e-wallet. However, the existing Information Technology (IT) infrastructure is not adequate to satisfy the bulk demand that is anticipated to occur in the future. Studies show that the lack of a trusted infrastructure may explain the low rate of cashless payments, which currently accounts for just 5\% of total daily payments in Malaysia, despite the technology-driven initiatives of the last two decades (Povera, 2020). Ensuring the network's security is critical to the success of a cashless payment system and electronic wallets are the vital components which do run the risk of hacking and other cyber-crimes. This risk factor is a serious one and discourages many people from adopting it. When all financial transactions depend on technology then the risk is magnified.

Although fintech has created new business opportunities and transmission of financial information from country to country, the products and services provided by fintech can be challenging to businesses and how they develop. Hence, Bank Negara Malaysia (BNM) and Securities Commission (SC) together ensured that Regtech made efforts to protect consumers and financial institutions. Regtech consists of a group of companies that help businesses to comply with regulations properly and less expensively by using cloud-based technology. BNM and SC have played an important role in Regtech to guide the application programming technology (API) requirements and guidelines (Figure 6). Meanwhile, BNM launched the electronic Know-Your-Customer in June 2020 to reduce the need for human intervention. 


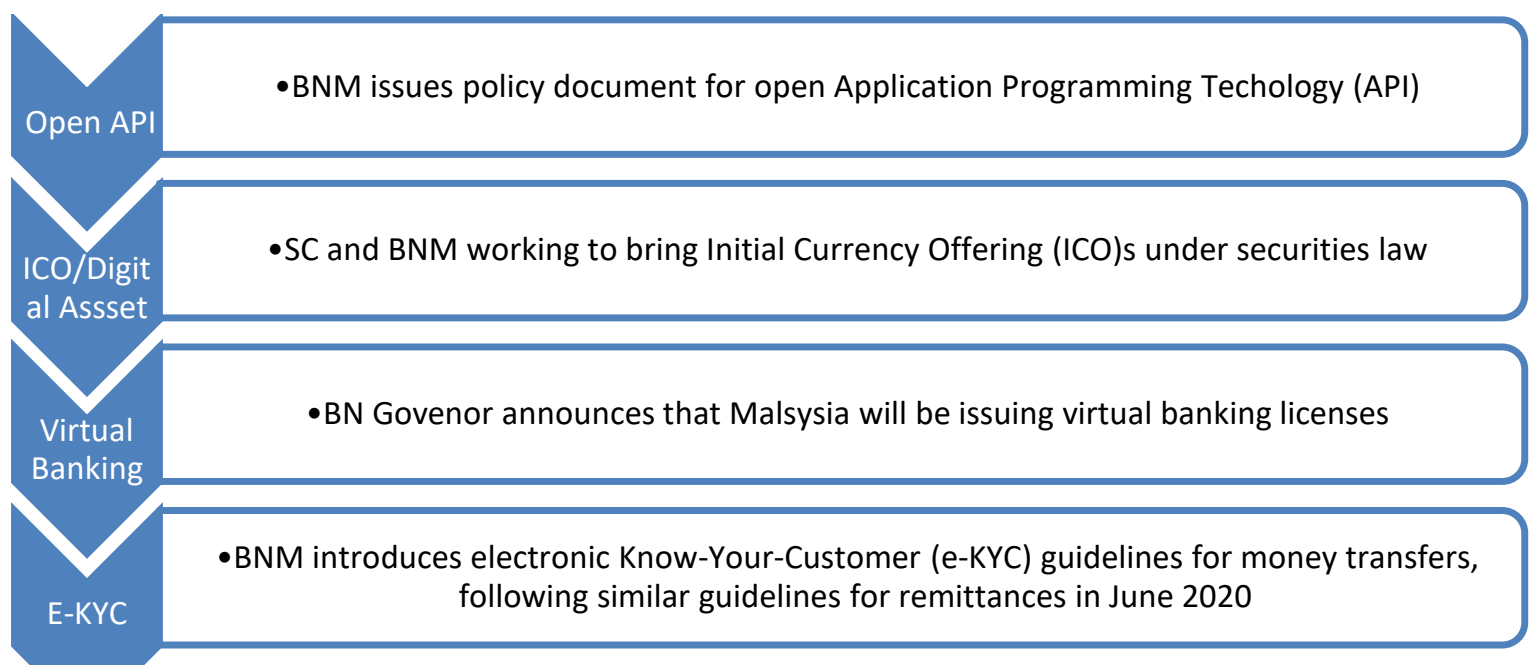

Figure 6: Fintech and Regulatory in Malaysia

Source: Fintech News Malaysia, 2020

There are two issues that reveal the most important weaknesses for a robust e-wallet market in Malaysia. First, as a developing nation, the majority of the population are not on good incomes or have a high level of education. There is consequently a lack of awareness among them about the benefits and threats of using e-wallets; this is why the growth of the e-wallet market is slow. Raising awareness will require nationwide financial and technological literacy programs focusing on the use and benefits of e-wallets. Secondly, Malaysia is a large country consisting of 2 large islands divided into several states. This has caused the uneven distribution of infrastructure and communication facilities that are not yet available in all parts of the country. This has become a huge challenge for the government and its ability to ensure the equitable development of infrastructure and communication facilities in all places. When adequate infrastructure and communication facilities are in place, it will be easier for economic transactions to be carried out using the e-wallet.

Although the e-wallet creates many challenges in legislation, regulations and traditional business models, it has important multifunctional uses that will benefit economic and financial services in Malaysia. If Malaysia can implement extensive e-wallet services, then the e-wallet can play vital role in monitoring public sector or administration irregularities such as scams, fraud and theft. This will contribute to strengthened and enforced government policies throughout the country and the beneficiaries will be those who use e-wallets. Besides, cashless transactions could greatly reduce crimes like bank robberies and muggings. Frauds that do occur with an e-wallet will still be recorded and the event can be tracked down and punished, which is generally not possible in a paper currency transaction case. Moreover, from the public revenue earning perspective, the e-wallet has great potential to generate income tax revenue. Due to the digital transaction system, all financial transactions will be recorded properly and widespread tax avoidance will be averted to some extent. The transparency of economic affairs will prevent the 'black economy' from operating or starting up.

\section{Conclusion}

The e-wallet is a system that enables and informs individuals about the advantages of digital transactions in their daily lives. All financial transactions, if carried out electronically, will lead to a more transparent and accountable culture, from a person's salary to mobile phone 
recharging. It may not be possible to switch from existing payment methods to fully cashless payment methods in the near future, but rapid advances in digital payment mechanisms will certainly improve societal access to cashless payments. Meanwhile the implementation of one method of cashless payment will impact on another form of cashless payment and eventually it will bring about a significant change. Therefore, this study examines the prospects and challenges of using the e-wallet in Malaysia. This study shows that Malaysia has very good prospects for using the e-wallet payment system but there are some issues. These include having adequate infrastructure, complexity of using e-wallet, cyber security, privacy risk and fintech regulations - all issues which need to be resolved in order to exploit this emerging technology. The SWOT analysis identified several strengths, weaknesses, opportunities and threats related to e-wallets in business development in Malaysia. It is recognised that the acceptance rate of this structure is still low.

Currently, entrepreneurs should pay attention to what enhances e-wallet services, especially with reference to what customers want or need in their e-wallet. Financial services should boost the speed and convenience of purchases in order to maximise market appeal. In this way they will have the ability to compete in the market. Though this study will play an important role for policymakers and e-wallet service providers to develop appropriate strategies to enhance ewallet services in Malaysia, it has some limitations. This study only focused on a SWOT analysis which does not indicate how to achieve competitive advantage or efficiency. Therefore, to draw more substantive conclusions, future research can focus on the variations between gender and ethnicity when it comes to the acceptance of e-wallets, and how cyber security or privacy protection issues are perceived. Similarly, studies also need to check what the issuers or vendors of e-wallets consider to be important.

\section{References}

Alt, R., Beck, R., \& Smits, M. T. (2018). FinTech and the transformation of the financial industry. Electronic Markets, 28(3), 235-243.

Andrew, J. V., Ambad, N. A. \& Tan, K. E. (2020). A Model of Factors Influencing Consumers' Intention to Use e-Wallet System in Malaysia: A Systematic Review. Malaysian Journal of Business and Economics, 6(2), 53-62.

Arner, D. W., Barberis, J. N., \& Buckley, R. P. (2015). The Evolution of Fintech: A New PostCrisis Paradigm? SSRN Electronic Journal, January. https://doi.org/10.2139/ssrn.2676553

Assenmacher, K. \& Krogstrup, S. (2018). Monetary Policy with Negative Interest Rates: Decoupling Cash from Electronic Money. IMF Working Paper No. 18/191, August. Available at SSRN: https://ssrn.com/abstract=3257357

Bank Negara Malaysia. (2011). Financial Sector Blueprint 2011-2020. Strengthening Our Future, LXIX(4), 1-198.

Bank Negara Malaysia. (2020). List of Non-bank E-money issuers. Retrieved from https://www.bnm.gov.my/index.php?ch=ps\&pg=ps_nonbank_emoney (Accessed on 29 Nov 2020)

Becker, J., Kugeler, M., \& Rosemann, M. (2011). Process Management: a guide for the design of business processes. 2nd ed. Springer-Verlag Berlin Heidelberg.

BNM (2018), Monthly Statistical Bulletin June 2018, Bank Negara Malaysia, Kuala Lumpur. Available

at: www.bnm.gov.my/index.php?ch=en_publication\&pg=en_msb\&lang=en\&mnth $=6 \& y \mathrm{r}=$ 2018 (Accessed on 28 August 2020)

Boamah, E. F., \& Murshid, N. S. (2019). "Techno-market fix"? Decoding wealth through 
mobile money in the global South. Geoforum, 106, 253-262.

Cennamo, C., \& Santaló, J. (2015). How to avoid platform traps. MIT Sloan Management Review, 57(1), 12.

Chauhan, S. (2015). Acceptance of mobile money by poor citizens of India: Integrating trust into the technology acceptance model. Info, 17 (3), 58-68.

Chen, L. (2016). From fintech to finlife: The case of fintech development in China. China Economic Journal, 9(3), 225-239.

Chew, B.C., Shen, X. \& Ansell, J. (2020), Alipay entered Malaysia: a closer look at the new market entry strategy driven by Chinese tourists, Qualitative Research in Financial Markets, 12(4), 561-577. https://doi.org/10.1108/QRFM-06-2019-0069

Chew, B.C., Shen, X. and Ansell, J. (2020). Alipay entered Malaysia: a closer look at the new market entry strategy driven by Chinese tourists, Qualitative Research in Financial Markets, 12 (4), 561-577. https://doi.org/10.1108/QRFM-06-2019-0069

Chew, Jeremy (2019). Which E-wallet App Do Malaysians Use Frequently?, October 29. Retreived from https://iprice.my/trends/insights/best-ewallet-malaysia/ (Accessed on 29 Nov 2020)

Chiu, I. H. (2017). A new era in fintech payment innovations? A perspective from the institutions and regulation of payment systems. Law, Innovation and Technology, 9(2), 190-234.

Choi, H., Park, J., Kim, J., \& Jung, Y. (2020). Consumer preferences of attributes of mobile payment services in South Korea. Telematics and Informatics, 51(June 2019), 101397.

Das Nair, R., \& Landani, N. (2020). Making agricultural value chains more inclusive through technology and innovation, World Institute for Development Economic Research (UNUWIDER). Working Paper \#2020-38.

De Luna, I. R., Liébana-Cabanillas, F., Sánchez-Fernández, J., \& Muñoz-Leiva, F. (2019). Mobile payment is not all the same: The adoption of mobile payment systems depending on the technology applied. Technological Forecasting and Social Change, 146(August), 931-944.

Fintech Malayisa, (2019). Touch'N Go E-Wallet Malaysia Fintech Report 2019. Retrieved from https://fintechnews.my/wp-content/uploads/2019/12/Touch-N-Go-eWalletMalaysia-Fintech-Report-2019_compressed-final.pdf (Accessed on 29 Nov 2020)

Fintech News Malaysia, (2020, June 30). Bank Negara Malaysia Unveils New eKYC Guidelines Ahead of Its Virtual Banking Framework. Retrieved from https://fintechnews.my/24197/digital-transformation/ekyc-malaysia-guideline-bnm/ (Accessed on 29 Nov 2020)

Gomber, P., Kauffman, R. J., Parker, C., \& Weber, B. W. (2018). On the Fintech Revolution: Interpreting the Forces of Innovation, Disruption, and Transformation in Financial Services. Journal of Management Information Systems, 35(1), 220-265.

Gomber, P., Koch, J. A., \& Siering, M. (2017). Digital Finance and FinTech: current research and future research directions. Journal of Business Economics, 87(5), 537-580. https://doi.org/10.1007/s11573-017-0852-x

Grigg, D. M., Tuders, J. F., Bertanzetti, P. J., \& England, T. (2014). U.S. Patent No. 8,666,895. Washington, DC: U.S. Patent and Trademark Office.

Grönroos, C. (1997). Value-driven relational marketing: from products to resources and competencies. Journal of marketing management, 13(5), 407-419.

GSMA (2018). The Mobile Economy Sub-Saharan Africa 2018. GSMA Intelligence. London, United Kingdom.

Gupta, A., \& Gupta, M. (2013). Electronic Mode Of Payment - A Study Of Indian banking System. International Journal of Enterprise Computing and Business System, 3(2), 1-13.

Haddad, C., \& Hornuf, L. (2019). The emergence of the global fintech market: economic and 
technological determinants. Small Business Economics, 53(1), 81-105.

Hagiu, A., \& Rothman, S. (2016). Network effects aren't enough. Harvard business review, 94(4), 64-71.

Hammer, M., \& Champy, J. (1993). Business process reengineering. London: Nicholas Brealey, 444(10), 730-755.

Hess, P. (2017). The Ongoing Evolution of Payment Instruments in China: A Case Study in Financial Innovation, and on the Role of the Central Bank. In Cash in East Asia (pp. 117131). Springer, Cham.

Hung, J., \& Luo, B. (2016). FinTech in Taiwan: a case study of a Bank's strategic planning for an investment in a FinTech company. Financial Innovation, 2, 1-16.

Jayaseelan, R. (2017), The e-wallet race hots up, The Star, Jul 29. Available at https://www.thestar.com.my/business/business-news/2017/07/29/the-ewallet-race-hotsup/ (Accessed on 20 April 2021)

Jayaseelan, R. (2017), The e-wallet race hots up, The Star, Jul 29. Available at https://www.thestar.com.my/business/business-news/2017/07/29/the-ewallet-race-hotsup/ (Accessed on 20 April 2021)

Jayaseelan, R. (2017). The e-wallet race hots up. The Star Online. Business section. Jul 29.

Kang, J. (2018). Mobile payment in Fintech environment: trends, security challenges, and services. Human-Centric Computing and Information Sciences, 8, Article No. 32. https://doi.org/10.1186/s13673-018-0155-4

Karim, M. W., Haque, A., Ulfy, M. A., Hossain, M. A., \& Anis, M. Z. (2020). Factors influencing the use of E-wallet as a payment method among Malaysian young adults. Journal of International Business and Management, 3(2), 01-12.

Kauffman, R.J., Ma, D., 2015. Special issue: Contemporary research on payments and cards in the global fintech revolution. Electron. Commer. Res. Appl. 14, 261-264. https://doi.org/10.1016/j.elerap.2015.09.005

Kazan, E., Tan, C. W., Lim, E. T., Sørensen, C., \& Damsgaard, J. (2018). Disentangling digital platform competition: The case of UK mobile payment platforms. Journal of Management Information Systems, 35(1), 180-219.

Kerényi, Á., \& Molnár, J. (2017). The Impact of the Fintech Phenomenon - Radical Change Occurs in the Financial Sector? Hitelintézeti Szemle, 16(3), 32-50.

Lashitew, A. A., Van Tulder, R., \& Liasse, Y. (2019). Mobile phones for financial inclusion: What explains the diffusion of mobile money innovations?. Research Policy, 48(5), 12011215.

Leong, C. M., Tan, K. L., Puah, C. H. \& Chong, S. M. (2021), Predicting mobile network operators users m-payment intention, European Business Review, 33 (1). https://doi.org/10.1108/EBR-10-2019-0263

Loh, X. M., Lee, V. H., Tan, G.W. H., Ooi, K. B. \& Dwivedi, Y.K. (2021), Switching from cash to mobile payment: what's the hold-up?, Internet Research, 31(1), 376399. https://doi.org/10.1108/INTR-04-2020-0175

Luna-Martinez, D. (2017). Financial inclusion in Malaysia: Distilling lessons for other countries (No. 115155, pp. 1-68). The World Bank, Washington, DC.

Milian, E. Z., Spinola, M. D. M., \& de Carvalho, M. M. (2019). Fintechs: A literature review and research agenda. Electronic Commerce Research and Applications, 34, 100833.

Muslimin, (2020). Ultimate Guide To E-Wallet In Malaysia 2020 - Which Should You Get?, June 12. Retrieved from https://www.comparehero.my/e-wallet/articles/best-ewalletmalaysia\#list-ewallets-malaysia (Accessed on 29 Nov 2020)

Navaretti, G. B. mname, Calzolari, G. mname, Mansilla-Fernandez, J. M. mname, \& Pozzolo, A. F. mname. (2018). Fintech and Banking. Friends or Foes? SSRN. https://doi.org/10.2139/ssrn.3099337 
Niranjanamurthy, M., Kavyashree, N., Jagannath, S., \& Chahar, D. (2013). Analysis of ecommerce and m-commerce: advantages, limitations and security issues. International Journal of Advanced Research in Computer and Communication Engineering, 2(6), 23602370.

Nizam, F., Hwang, H. J., \& Valaei, N. (2019). Measuring the effectiveness of E-wallet in Malaysia. In Studies in Computational Intelligence (Vol. 786). Springer International Publishing.

OPPOTUS (2019). E-Wallets in Malaysia: Landscape at the End of 2019. December. Retrieved from https://www.oppotus.com/e-wallets-malaysia-landscape-end- 2019/ (Accessed on 29 Nov 2020)

Palmié, M., Wincent, J., Parida, V., \& Caglar, U. (2020). The evolution of the financial technology ecosystem: An introduction and agenda for future research on disruptive innovations in ecosystems. Technological Forecasting and Social Change, 151(June), 119779.

Povera, A. (2020). Central payment infrastructure providers needed to make Msia cashless. January $20 . \quad$ Retrieved from https://www.nst.com.my/news/nation/2020/01/558250/central-payment-infrastructureproviders-needed-make-msia-cashless (Accessed on 28 August 2020)

Salah Uddin, M., \& Yesmin Akhi, A. (2014). E-Wallet System for Bangladesh an Electronic Payment System. International Journal of Modeling and Optimization, 4(3), 216-219.

Salampasis, D., \& Mention, A. L. (2018). FinTech: Harnessing Innovation for Financial Inclusion. In Handbook of Blockchain, Digital Finance, and Inclusion (1st ed., Vol. 2). Elsevier Inc.

Schindler, J. (2017). FinTech and Financial Innovation: Drivers and Depth, Finance and Economics Discussion Series 2017-081. Washington: Board of Governors of the Federal Reserve System.

Shaikh, A. A., Glavee-Geo, R., \& Karjaluoto, H. (2017). Exploring the nexus between financial sector reforms and the emergence of digital banking culture - Evidences from a developing country. Research in International Business and Finance, 42(December), 1030-1039.

Shekhar, S., Manoharan, B., \& Rakshit, K. (2020). Going cashless: Change in institutional logic and consumption practices in the face of institutional disruption. Journal of Business Research, 114(April), 60-79.

Singh, N., Sinha, N., \& Liébana-Cabanillas, F. J. (2020). Determining factors in the adoption and recommendation of mobile wallet services in India: Analysis of the effect of innovativeness, stress to use and social influence. International Journal of Information Management, 50 (October), 191-205.

Susanto, P., Hoque, M. E., Hashim, N. M. H. N., Shah, N. U. \& Alam, M. N. A. (2020), Moderating effects of perceived risk on the determinants-outcome nexus of e-money behaviour", International Journal of Emerging Markets. https://doi.org/10.1108/IJOEM05-2019-0382

Tajudin, M. M., \& Musa, N. C. (2018). Issues and Trends in Open Innovation amongst Malaysian Fintech Start-ups. International Journal of Academic Research in Business and Social Sciences, 8(9), 1949-1964.

Tan, J. D., Purba, J. T., \& Widjaya, A. E. (2019). Financial Technology as an Innovation Strategy for Digital Payment Services in the Millenial Generation. In 1st Aceh Global Conference (AGC 2018), January, Atlantis Press.

Teoh Teng Tenk, M., Yew, H. C., \& Heang, L. T. (2020). E-Wallet Adoption: A Case in Malaysia. International Journal of Research in Commerce and Management Studies, 2(2), 216-233. 
Tun-Pin, C., Keng-Soon, W. C., Yen-San, Y., Pui-Yee, C., Hong-Leong, J. T., \& Shwu-Shing, N. (2019). An adoption of fintech service in Malaysia. South East Asia Journal of Contemporary Business, 18(5), 134-147.

Uddin, M. S., \& Akhi, A. Y. (2014). E-wallet system for Bangladesh an electronic payment system. International Journal of Modeling and Optimization, 4(3), 216.

Venkatraman, N. (1994). IT-enabled business transformation: from automation to business scope redefinition. Sloan management review, 35, 73-73.

Venkatraman, N. (2000). Five steps to a dot-com strategy: How to find your footing on the Web. MIT Sloan Management Review, 41(3), 15.

Ventures Scanners (2017). Financial Technology Companies Founded by Year-Q3 2017. August 31. Retrieved from https://www.venturescanner.com/2017/08/31/financialtechnology-companies-founded-by-year-q3-2017/. (Accessed on 29 Nov 2020

Wikipedia. (2020). Financial technology. https://en.wikipedia.org/wiki/Financial_technology (Accessed on 29 Nov 2020)

World Bank (2018). Retrieved from http://data.worldbank.org/ (Accessed on 29 Nov 2020)

Yaokumah, W., Kumah, P., \& Okai, E. S. A. (2017). Demographic influences on E-payment services. International Journal of E-Business Research, 13(1), 44-65.

Zhiming, Z., Tao, C., Hailiang, C., \& Qianyi, D. (2013). Journal of business management studies. Journal of Business Management \& Economics, 1(1), 23-30.

\section{Author's Biography:}

Dr. Md. Mahmudul Alam is an Associate Professor at Universiti Utara Malaysia and an Associate Fellow at University Technology MARA (Malaysia). He is a certified Financial Planner and certified Expert in Climate Adaptation Finance. He was awarded the AFFP Research Fellowship from FS-UNEP Centre (Germany) and recognized by the BDRC (USA) as one of the "Top Bangladesh Development Researchers of the Millennium". He obtained his $\mathrm{PhD}$ and Master's degrees from the National University of Malaysia. To date he has published more than 150 journal articles and presented more than 100 articles at conferences. His research areas include sustainable finance, sustainable development, ecological economics, financial economics, fintech, and Islamic finance and economics.

Dr. Ala Eldin Awawdeh is currently working as Assistant Professor in the Department of Management at Emirates College of Technology, UAE. He has earned his PhD from the Faculty of Economic Sciences and Management, University of Pisa, Italy. He obtained his Master's degree from the Faculty of Economic Sciences and Management, University of Pisa, Italy, and Bachelor degree from the Faculty of Economic Sciences and Management, University of Mutah, Jordan. He has experiences of teaching at University of Alain (UAE), Khawarizmi International College (UAE) and Toledo College (Jordan). His research interest is business management and development.

Mr Azim Izzuddin Bin Muhamad is a senior lecturer of Finance at Universiti Teknologi MARA Malaysia. He obtained his Master's degrees in Finance from Universiti Teknologi MARA Malaysia. His research areas include entrepreneurial finance, portfolio management, sustainable business, sustainable development, and agro business. 